\title{
Oral Administration of Encapsulated Bovine Lactoferrin Protein Nanocapsules Against Intracellular Parasite Toxoplasma gondii [Corrigendum]
}

Anand N, Sehgal R, Kanwar R, Dubey M, Vasishta RK, The correct Figure 2 is shown below.

Kanwar J. Int J Nanomedicine. 2015;10:6355-6369.

The authors have advised due to an error that occurred inad-

The authors apologize for this error and advise it does not vertently at the time of figure assembly the incorrect images affect the results and conclusions of the paper.

were selected by the first author for Figure 2 on page 6361.

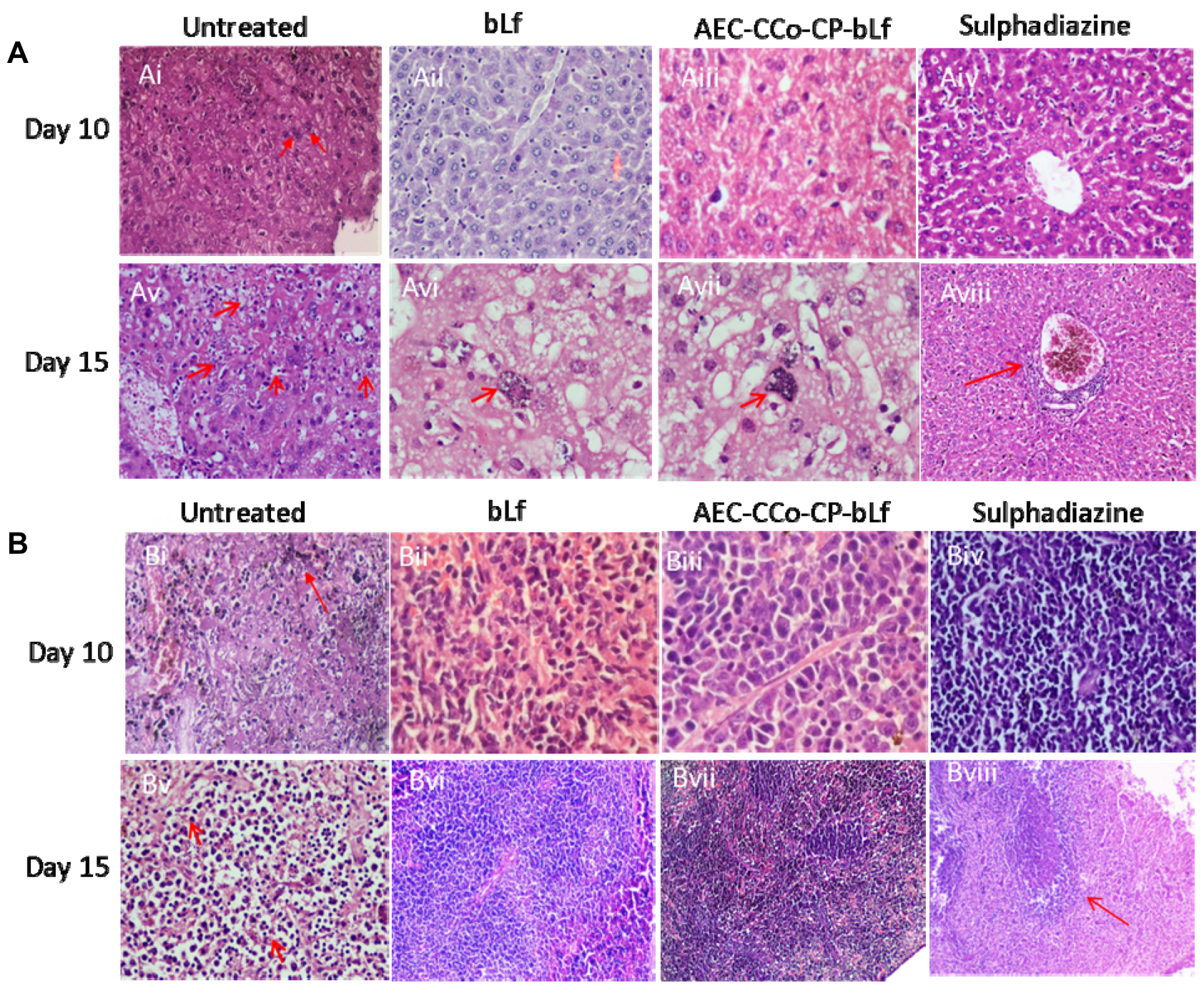

Figure 2 Histopathological analysis in liver (A) and spleen (B) at day 10 and 15 post infection.

Notes: (Ai) Liver histopathology of untreated group of mice at day 10 post infection showing the presence of tachyzoites (marked with red arrows). (Aii-iv) Liver histopathology of treatment groups showing no sign of inflammation or parasite at day 10 post infection. (Av) Untreated control group showing huge number of infected macrophages marked by red arrows. (Avi-vii) bLf and NCs treatment groups showing development of bradyzoites or tissue cyst inside the macrophages (Kupffer cells) marked by red arrows. (Aviii) Sulphadiazine treatment group showing no infection but sign of inflammation marked by red arrow. (Bi) Untreated Spleen cells showing site of tachyzoite multiplication (red arrow). (Bii-iv) Treatment groups showing no sign of inflammation or infection. (Bv) Spleen histopathology at day 15 post infection showing multiple sites (50\%) with tachyzoites marked with red arrows. (Bvi-vii) No parasite infection shown in treatment groups, however, inflammation and reactive spleen was seen in sulphadiazine group (Bviii) marked as red arrow.

Abbreviations: AEC-CCo-CP-bLf, alginate chitosan calcium phosphate bovine lactoferrin; bLf, bovine lactoferrin.

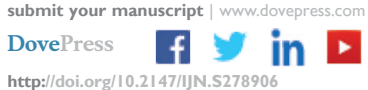

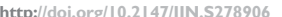




\section{Publish your work in this journal}

The International Journal of Nanomedicine is an international, peerreviewed journal focusing on the application of nanotechnology in diagnostics, therapeutics, and drug delivery systems throughout the biomedical field. This journal is indexed on PubMed Central, MedLine, CAS, SciSearch ${ }^{\circledR}$, Current Contents ${ }^{\circledR} /$ Clinical Medicine, $^{2}$
Journal Citation Reports/Science Edition, EMBase, Scopus and the Elsevier Bibliographic databases. The manuscript management system is completely online and includes a very quick and fair peer-review system, which is all easy to use. Visit http://www.dovepress.com/ testimonials.php to read real quotes from published authors. 